Radmila Bjekić, Maja Strugar Jelača, Nemanja Berber, Marko Aleksić* University of Novi Sad, Faculty of Economics, Subotica, Serbia

\title{
Factors Affecting Entrepreneurial Intentions of Faculty Students
}

DOI: 10.7595/management.fon.2020.0024

Abstract:

Research Question: The authors of the article investigate if there is a relationship between the psychological characteristics of students at the Faculty of Economics and their entrepreneurial intentions. Motivation: Based on the study results of Littunen (2000), Walter et al. (2013) and Popescu et al. (2016), the authors planned to identify the factors which would predominately influence the students' entrepreneurial intentions. Idea: The authors believe that the psychological characteristics, such as the greater need for achievement and the need for independence can be treated as important psychological indicators for the students' predicted entrepreneurial success in the future. Furthermore, these characteristics are significant but not sufficient, therefore the introduction of formal entrepreneurial education at university is likely to additionally contribute to raising the students' entrepreneurial spirit. Data: The research was conducted during the academic year of 2016/17 on a sample of 517 students in their third and fourth years of studies at the Faculty of Economics. The survey questionnaire adopted already established scales on students' entrepreneurial intentions as created and carried out by Walter, Parboteeah and Walter (2013). Tools: The PLS analysis was used for exploring relations between psychological characteristics (Need for Achievement and Need for Independence) and entrepreneurial intentions. For that purpose, the authors used Smart PLS 3 software. Findings: The results show that psychological characteristics are significantly related to students' entrepreneurial intentions, i.e., the students who have a greater need for achievement and independence, also have stronger entrepreneurial intentions in comparison with those who do not have those needs. Contribution: The paper contributes to the literature by empirically testing how certain factors affect the entrepreneurial intentions of university students of economics.

Keywords: students, entrepreneurial intentions, entrepreneurial spirit, psychological characteristics

JEL Classification: I23, M13

\section{Introduction}

Entrepreneurship is a phenomenon that increasingly occupies the attention of scientists, researchers, educators, and even young people. Programmes for promoting entrepreneurship among pupils and encouraging their entrepreneurial spirit are introduced in the early days of schooling. Such programmes are increasingly promoted, and certainly during university studies, such forms of support should be intensified. Universities are more and more considered as key institutions that provide vital resources for society to learn about, aspire to and develop an entrepreneurial spirit which can foster entrepreneurship (Souitaris et al., 2007). Entrepreneurial activity is regarded as imperative for the health of the developing countries and presents the basis of economic activities in such areas (Petrovic \& Lekovic, 2019). Also, today more and more important social entrepreneurship is developing with the same purpose, but in a different way, namely, through socially responsible practices of commercial enterprises engaged in cross-sector partnerships (Mitrovic \& Mitrovic, 2019). This is seen as a force that revitalizes the economy and contributes to economic progress and job creation. Therefore, the development of entrepreneurship is encouraged, given that it sup- 
ports the national economic policy in order to stimulate economic growth (Zaman, 2013). The underlying reason for the increased focus on entrepreneurship is the fact that in 2017, the unemployment rate in Serbia was $13.5 \%$, while in terms of "brain drain", Serbia is among the highest-ranking countries in the world. It is very important to emphasise that the youth unemployment rate in the same period was $31.9 \%$ (Statistical Office of the Republic of Serbia, 2018:7-8). Thus, the 'support for entrepreneurial youth' initiatives are one of the key factors for improving employment and keeping young people in Serbia.

The authors of the paper were motivated by the above facts and decided to launch a research on students' entrepreneurial intentions, starting with the Faculty of Economics in Subotica, hoping to stimulate a series of research works in this area. This would create a unique database, detect the deficiencies, find the best mechanisms of work and ultimately support and develop the entrepreneurial spirit of young people.

In this paper, the authors investigate whether there is a relationship between students' psychological characteristics and their entrepreneurial intentions. The idea of this research was based on the results of earliest research that emphasised the importance of psychological characteristics as determinants of entrepreneurial intentions (Matlay et al., 2013) as well as that this research topic re-emerged after 20 years (Zhao et al., 2010) and still attract considerable attention (Zhao et al., 2010; Bux \& Honglin, 2015; Nasip et al., 2017; Gu et al., 2018). One of the reasons why relations between psychological characteristics and entrepreneurial intentions should not be neglected can be found in Bird's (1988) widely known definition about entrepreneurial intentions "as the states of mind that direct attention, experience, and action toward a business concept" (p. 442). Therefore, psychological characteristics can be understood as a predictor of transformation of entrepreneurial intention into active entrepreneurial behaviour in some stage of life. The empirical results from the study of Ajzen, Csasch and Flood (2009) reveal the high positive relationship between entrepreneurial intention and entrepreneurial behaviour. Also, the entrepreneurial intention affects individual decision making according to entrepreneurial behaviour so it can be considered as its predictor. The link between these variables was the guiding idea for adopting new approaches in determining entrepreneurship intention concept. Nevertheless, psychological characteristics as one of the determinants of entrepreneurial intentions should not be abandoned because there were different research models and investigated hypotheses with confronting results (Zhao et al., 2010), and therefore, they should be studied in more detail in the future.

The study involved 517 students at the Faculty of Economics in Subotica, all in their third or fourth years of study, across various study programmes. Through this research, the authors explored the relationship between the psychological characteristics of students at the Faculty of Economics and their entrepreneurial intentions. For revealing the relations between psychological characteristics (Need for Achievement and Need for Independence) and entrepreneurial intentions the PLS was used. The results of the analysis showed that there was a positive relationship between students' psychological characteristics and their entrepreneurial intentions.

The paper is structured as follows: the first part contains a review of the relevant literature in this field, specifically the relationship between students' psychological characteristics and their entrepreneurial skills. Next, there is a description of the research method applied. The following section outlines the results of the conducted research and presents their analysis. The final part of the paper offers concluding observations and gives recommendations for future research.

\section{Theoretical Background}

Entrepreneurial intentions of an individual can be defined as their alleged desire to start a business or to found a new company in the future. Entrepreneurial intentions are desires to own or start a business (Bae et al., 2014). Entrepreneurial intentions can also be defined as the "self-acknowledged conviction by a person that they intend to set up a new business venture and consciously plan to do so at some point in the future" (Thompson, 2009: 676). They direct their attention, experience and behaviour towards a planned entrepreneurial action and play a crucial role in the development of entrepreneurial activities (Kautonen et al., 2015; Kibler et al., 2014). The application of intentions in the domain of entrepreneurship (self-employment) research started soon after Ajzen (1991) revised his theory of planned behavior.

Much research has been conducted and numerous papers written on the subject of students' entrepreneurial tendencies. Many authors linked entrepreneurial intentions with students' psychological characteristics and entrepreneurial education (Hansemark, 2003; Gürol, \& Atsan 2006; Walter et al., 2013; Ferreira et al., 2012; Dinis et al.,2013; Zaman, 2013; Ahmed et al., 2010; Stamboulis \& Barlas 2014, Popescu et al., 
2016) while a smaller number of authors focused on programmes of support to the development of entrepreneurial intentions of students (Souitaris et al., 2007; Walter et al., 2013).

In the majority of papers, the psychological characteristics associated with entrepreneurial intentions are: locus control (the degree to which individuals believe that their achievements depend on their own behavior), the tendency to take risks, self-confidence, the need to achieve, the tolerance of ambiguity and innovation (Ferreira et al., 2012). Ferreira et al. analyzed data using structural modelling equations, and also implemented a partial least squares (PLS) technique to test the model. Gürol and Atsan (2006) used six characteristics in their study in order to define the students' entrepreneurial profile. These are: the need to achieve, locus control, the tendency to risk, tolerance for ambiguity, innovation and self-confidence. The survey was conducted on a sample of 400 students of the fourth year of study at two universities in Turkey. For the analysis, the authors used the t-test and proved that, except for tolerance for ambiguity and self-confidence, all entrepreneurial traits were found to be higher in entrepreneurially inclined students, as compared with entrepreneurially non-inclined students. The results of the research showed that students who were more prone to risk had internal locus control, greater need for achievement and were more innovative, had a stronger inclination towards entrepreneurship in comparison to those who did not possess these psychological characteristics (Gürol \& Atsan, 2006).

Popescu et al. conducted a survey on a sample of 600 students in Romania. The research aimed to highlight how psychological characteristics affected the entrepreneurial intentions of students. The focus was on the following psychological characteristics: creativity, locus control, need for reaching and a tendency towards risk. The authors used several statistical techniques for testing research hypothesis, including Analysis of Variance (ANOVA), Principal Component Analysis (PCA) and General Linear Models (GLM). The results of the study showed that the need for achieving and the preference for risk influence student's entrepreneurial intentions and play a vital role regarding students' entrepreneurial preference (Popescu et al., 2016). For further analysis, the psychological characteristics of Need for Achievement and Need for Independence will be explained in more detail.

The Need for Achievement is an important determinant of individual entrepreneurial intentions. Individuals who have a strong need to achieve are in fact those who want to solve their problems by themselves, set goals and strive to achieve these goals through their own efforts. They also aim to show better results in challenging tasks, whereby they are more innovative in terms of seeking new and better ways to improve their performance (Littunen, 2000; Hansemark, 2003). McClelland (1961) proved that there was a relationship between the need for achievement and business development. In his wake, many authors showed that indeed there was a relationship between the need for achievement and entrepreneurial behaviour (Begley \& Boid, 1987). Further, there were numerous comparative studies on entrepreneurship and the differences between entrepreneurs and those who failed to determine that the need for achievement had a more significant connection with entrepreneurship than with other psychological characteristics analyzed (Littunen, 2000).

The Need for Independence refers to the need to execute something in the way the initiator planned,even in spite of conventional expectations. Autonomy is one of the most frequently stated reasons for choosing an entrepreneurial career (Kolvereid, 1996). The need for independence presents itself in those individuals who decline a work environment where they are subordinate; who are capable of independently defining the structure of their tasks, who crave the freedom to create assignments, but are also able to independently determine the time and order of the assigned tasks (Walter et al., 2013). According to Amidzic (2019), "opportunity entrepreneurs are motivated by prospects of increasing their wealth. They are looking for independence or new prospects in business, by creating opportunities that can provide a wide range of business ventures on the market" (p. 45). In their previous article, the present authors proved the hypothesis that "there is a statistically significant relationship between the students' need for greater achievement and independence, on the one hand, and their entrepreneurial intention, on the other" (Bjekic \& Strugar Jelaca, 2019, 384).

As regards supporting programmes for entrepreneurship development, the focus will be on the article that tested the multi-level model of self-employment intentions (Walter et al., 2013). Essentially, Walter et al. (2013) suggested that universities represented a contextual environment that affected students more than individual influences of self-employment intentions. Entrepreneurship support programmes measure the range of systematic and complementary institutional activities aimed at supporting students in developing an entrepreneurial career. Entrepreneurship support programmes include activities such as guest lectures, competition in compiling a business plan, extracurricular consulting, securing start-up capital. Walter et al., argued that students at universities with more active entrepreneurship support programmes would be more 
oriented towards creating an entrepreneurial career. The survey was conducted on a sample of 1530 students and 132 professors in 25 departments in Germany. For data analysis purposes, The results of the research indicated that there was no statistically significant relationship between entrepreneurship support programmes and self-employment intentions (Walter et al., 2013).

Although not the subject of this research, entrepreneurship education should be paid attention to since, in the present authors' opinion, programmes for supporting the development of entrepreneurship without entrepreneurial education at the university cannot produce significant results.

Entrepreneurship education is meant to enhance "awareness of entrepreneurship as an alternative career path to employment" (Slavtchev et al., 2012, 3). The results of the conducted research in this field showed that entrepreneurial education can significantly stimulate entrepreneurial intentions of students (Zhang et al., 2014; Bae et al., 2014; Maresch et al., 2016). The American education system was the first to introduce this type of education to students by offering courses and programmes in the field of entrepreneurship and creating an inspiring environment that stimulated and developed entrepreneurship (Pepen \& Pruett, 2014). Pepen \& Pruett (2014) stated that the most effective way to stimulate entrepreneurship was to motivate students through education and raising awareness about importance and benefits of entrepreneurship.

There are various forms of entrepreneurial education, such as courses for writing business plans that aim to provide knowledge and skills that reinforce entrepreneurial intentions (von Graevenitz et al., 2010), as well as courses for creating business ventures, where students learn how to take practical steps to start their own business, that is to start their own company (Rodrigues et al., 2012). A survey conducted on a sample of 170 students of basic academic studies in economics and mechanical engineering aimed to investigate the impact of education on the students' intentions to start their own business in Lithuania. The statistical technique used was the Kendall's Coefficient of Concordance (W). The results of the research demonstrated that students of economics held that education positively influenced their entrepreneurial intentions by providing them with the basic knowledge of business management and developing the needs for achieving them, while students of mechanical engineering believed that entrepreneurial education contributed very little to entrepreneurship development among young people (Remeikiene et al., 2013). The importance of entrepreneurial education at university was also reflected in the results of a research carried out by Franke and Luthje with the aim of comparing the entrepreneurial potential of German and American students. Those research results revealed that American students had higher entrepreneurial potential than German students, and the reason was the educational system that offered more specific entrepreneurial knowledge and skills. ANOVA was used for this purpose (Franke \& Luthje, 2004). It is accepted that entrepreneurial education and programmes supporting the entrepreneurial spirit development, along with the positive environment at the university, will positively contribute to entrepreneurial activity and the entrepreneurial potential of individuals. Hence it is suggested that universities should adopt and apply entrepreneurial education as much as possible, in order to create a good basis for the development of future entrepreneurs, and in that way contribute to the development of the economy as a whole. Many authors recommend that universities need to develop dynamic educational and entrepreneurial practice and provide space at the university where students will be able to put into practice the knowledge they have gained at the lectures (Díez-Echavarría et al., 2019).

Based on the presented theoretical framework and the ruling attitudes in this field, the following hypotheses have been set:

H1: Need for Achievement as psychological characteristic is positively related to entrepreneurial intentions of students at the Faculty of Economics

H2: Need for Independence as psychological characteristic is positively related to entrepreneurial intentions of students at the Faculty of Economics

\section{Methodology}

In order to ensure high regional representativeness of the data, it was decided to survey the largest public faculty for economics studies, specializing in business and management in the Autonomous Province of Vojvodina. The research was conducted during the academic year 2016/17 on a sample of students at the Faculty of Economics in Subotica. The same sampling procedure was used as in the research of the authors Walter et al. (2013). The authors worked with a stratified random sample of 517 students from the general population of 2777 students, who study economics and business in the academic courses at the University of Novi Sad. The survey was conducted at the beginning of one of the compulsory lectures for the students 
of the third and fourth years from all study programmes. This particular sampling strategy was selected because students in their third and fourth years of study have already partly made up their mind regarding future employment as they are aware of their abilities from the point of view of self-employment. Furthermore, the authors made sure to survey students from all study programmes without specifically oversampling entrepreneurially oriented students from the management study program.

The research-based questionnaire was formulated on the basis of a questionnaire on individual entrepreneurial intentions of students created and conducted by Walter, Parboteeah and Walter (2013) at selected universities in Germany. The Likert scale from 1 to 5 was used (1 - incorrect statement, 2 - partly incorrect, 3 - neither accurate nor incorrect, 4 - partially accurate, 5 - accurate).

The questionnaire consisted of 17 questions. The first three questions inquired about the respondent's general information, such as gender, study programme and year of study. Altogether 14 questions were used to measure Entrepreneurial Intentions, the Need for Achievement and the Need for Independence. Three questions were posed to test Entrepreneurial Intentions: (Z1) There is no doubt that I will become self-employed as soon as possible; (Z2) I plan on becoming self-employed within 5 years of the successful completion of my studies and (Z3) I plan on becoming self-employed sometime after the successful completion of my studies (Walter et al., 2013). Furthermore, certain questions measured the student's psychological characteristics, such as the Need for achievement: (A1) Hard work is something I like to avoid; (A2) I frequently think about ways I could earn a lot of money; (A3) I believe I would enjoy having authority over other people; (A4) I find satisfaction in exceeding my previous performance even if I don't outperform others; (A5) I care about performing better than others on a task; (A6) I would rather do tasks at which I feel confident and relaxed than do ones which appear challenging and difficult and (A7) I would like an important job where people look up to me (Cassidy \& Lynn 1989) and the Need for independence: (11) Having freedom of choice when I do my work is important to me; (I2) I prefer to determine the content of my work as far as possible on my own; (13) I would rather set the sequence of my work tasks on my own; (14) / dislike being subordinate to other people (Walter et al., 2013).

Table 1: Sample characteristics

\begin{tabular}{|l|r|r|}
\hline Characteristics & N & $\begin{array}{c}\text { Percentage of } \\
\text { sample }\end{array}$ \\
\hline Gender & 124 & 24 \\
Female & 389 & 76 \\
Male & & \\
\hline Year of the study & 207 & 40 \\
Third year & 310 & 60 \\
Fourth year & & \\
\hline Study program & 69 & 13.3 \\
Accounting and Auditing & 44 & 8.3 \\
Agrarian Economy and Agribusiness & 54 & 10.4 \\
Business Information Systems & 68 & 13.2 \\
European and International Economy and Business & 142 & 27.8 \\
Finance, Banking and Insurance & 27 & 5.2 \\
Management & 91 & 17.6 \\
Marketing & 20 & 3.9 \\
Commerce & 2 & 0.4 \\
Missing & 517 & 100 \\
\hline Total
\end{tabular}

Source: Authors' calculations

Out of 517 respondents, $24 \%$ i.e., 124 were female students, while the remaining $76 \%$ were made up of 389 male students. A total of 207 participants were in their third year of studies, whereas 310 respondents, or $60 \%$ of all respondents attended the fourth year at university. Based on the criteria of the study program, the structure of the sample was as follows: the largest number of respondents, 142 students, studied FBI (Finance, banking and insurance), thus making up $27 \%$ of the overall number of students, while the smallest number of respondents studied Commerce $-3.9 \%$. The layout of the above data follows logically from the 
structure of student enrollment at the faculty: the largest number of students are enrolled in the FBI study programme, whereas Commerce has the fewest students. Concerning the other study programmes, the structure is given here: Marketing accounted for 17.6\%, Accounting and Auditing amounted to 13.3\%; European and International Economy and Business provided $13.2 \%$ of the respondents; Business Information Systems students made up 10.4\%; Agrarian Economy and Agribusiness was studied by $8.3 \%$, while Management students accounted for $5.2 \%$ of the overall number of survey participants.

\section{Results and Discussion}

The authors analyzed reflective indicator loading, internal consistency reliability, convergent validity and discriminant validity. This type of measurement is suggested for reflective constructs in the model (Hair et al., 2019, Grubor et al., 2018). In addition to the methods listed above, common method bias (CMB) was also performed. First, however, certain variables were removed from the analysis, because their loadings were very low. According to Hair et al. (2019) the lowest limit of acceptability is 0.708 . Factors which have loading between 0.4 and 0.7 should be retained if their deletion does not have a positive impact on AVE and Composite Reliability (Hair et al., 2014). Based on the abovementioned, the authors retained only one item with loadings below the threshold of 0.708 (see Figure 1).

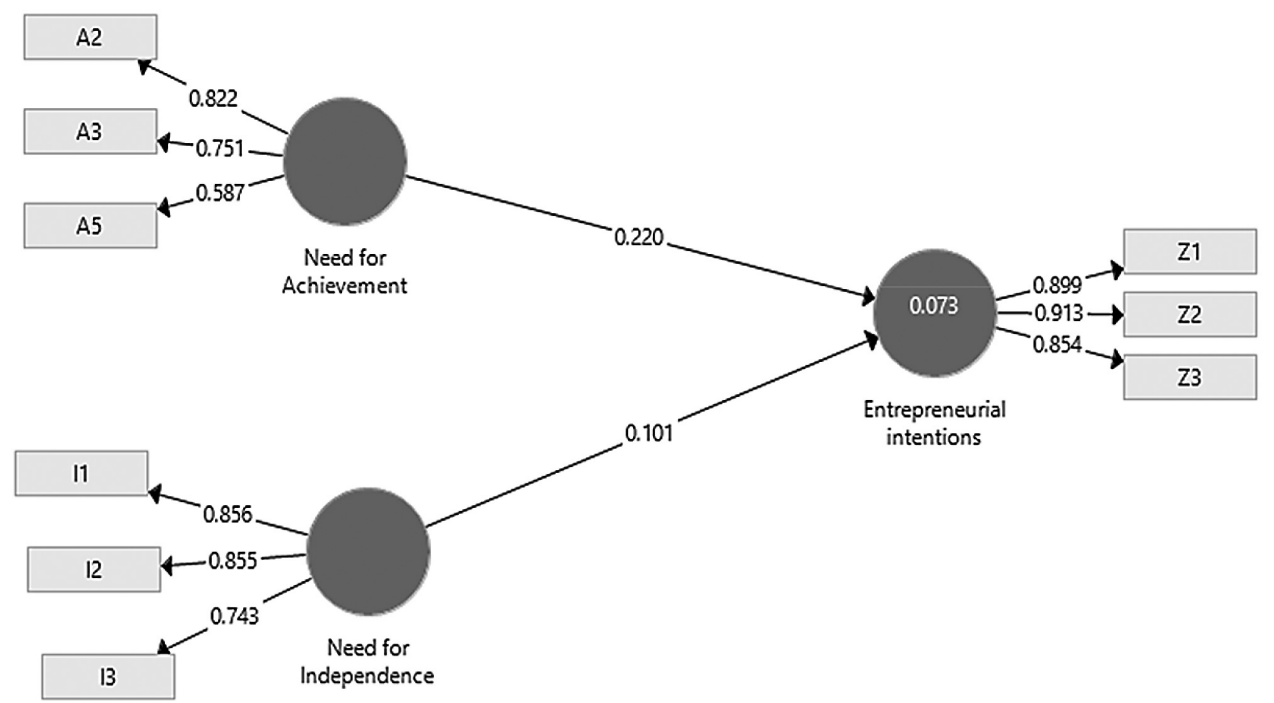

Figure 1: Path coefficient estimates

Source: Authors' own research

Table 2: Indicator reliability and construct reliability and validity

\begin{tabular}{|l|c|c|c|}
\hline & Cronbach's Alpha & Composite Reliability & AVE \\
\hline Entrepreneurial Intentions & 0.867 & 0.919 & 0.790 \\
\hline Need for Achievement & 0.564 & 0.767 & 0.528 \\
\hline Need for Independence & 0.769 & 0.859 & 0.672 \\
\hline
\end{tabular}

Source: Authors' calculation

The reliability test was conducted by calculating the Cronbach's alpha, composite reliability, and AVE.

Table 2 presents the results of this sample and shows that Cronbach's alpha values range from 0.564 (Need for Achievement), over 0.769 (Need for Independence) to 0.889 (Entrepreneurial Intentions). Some authors recommend that the lowest limit of acceptability should be 0.6 (Dakduk et al., 2019).

The value of the composite reliability of constructs (CR) ranges from 0.767 (Need for Achievement) through 0.859 (Need for Independence) to 0.919 (Entrepreneurial Intentions). The lowest limit of acceptability for composite reliability is 0.7 (Hair et al., 2014), so the results seen in Table 1 indicate that the composite reliability criterion is met.

Some researchers prefer the use of Composite Reliability rather than Cronbach Alpha, because Cronbach Alpha is being criticized for its lower bound value which underestimates the true reliability. CR can be used 
as an alternative, as its CR value is slightly higher than Cronbach Alpha, whereby the difference is relatively inconsequential (Peterson \& Kim, 2013).

The assessment of convergent validity was carried out based on the examination of the average extracted variance (AVE). In the model, the AVE value ranges from 0.528 (Need for Achievement), over 0.672 (Need for Independence) to 0.790 (Entrepreneurial Intentions). Bearing in mind that the lowest limit of acceptability is 0.5 (Fornell \& Larcker, 1981), it can be concluded that convergent validity is satisfied for all three constructs.

The discriminant validity can be evaluated by using cross-loadings of indicators, Fornell \& Larcker criterion and Heterotrait-monotrait (HTMT) ratio of correlation (Ab Hamid et al., 2017).

Table 3: Discriminant validity (Cross-loadings)

\begin{tabular}{|l|l|l|l|}
\hline & $\begin{array}{l}\text { Entrepreneurial } \\
\text { intentions }\end{array}$ & Need for Achievement & Need for Independence \\
\hline Z1 & $\mathbf{0 . 8 9 9}$ & 0.223 & 0.133 \\
\hline Z2 & $\mathbf{0 . 9 1 3}$ & 0.227 & 0.161 \\
\hline Z3 & $\mathbf{0 . 8 5 4}$ & 0.226 & 0.167 \\
\hline A2 & 0.234 & $\mathbf{0 . 8 2 2}$ & 0.178 \\
\hline A3 & 0.175 & $\mathbf{0 . 7 5 1}$ & 0.278 \\
\hline A5 & 0.123 & $\mathbf{0 . 5 8 7}$ & 0.328 \\
\hline I1 & 0.175 & 0.256 & $\mathbf{0 . 8 5 6}$ \\
\hline I2 & 0.143 & 0.320 & $\mathbf{0 . 8 5 5}$ \\
\hline I3 & 0.081 & 0.237 & $\mathbf{0 . 7 4 3}$ \\
\hline
\end{tabular}

Source: Authors' calculation

A measurement model has adequate discriminant validity when an indicator's loading is higher for its respective construct than for any constructs (Chin, 1998). The results presented in Table 3 demonstrate that the loading of each block is higher than any other block in the same rows and columns, clearly separating each latent variable Thus, the cross-loading output confirms the measurement model's discriminant validity.

Table 4: Discriminant Validity - Fornell-Larcker Criterion

\begin{tabular}{|l|c|c|c|}
\hline & Entrepreneurial Intentions & Need for Achievement & Need for Independence \\
\hline Entrepreneurial Intentions & $\mathbf{0 . 8 8 9}$ & & \\
\hline Need for Achievement & 0.254 & $\mathbf{0 . 7 2 7}$ & \\
\hline Need for Independence & 0.174 & 0.330 & $\mathbf{0 . 8 1 9}$ \\
\hline
\end{tabular}

Source: Authors' calculation

According to Fornell-Larcker criterion, the root from the AVE of a latent variable must have a higher value than all correlations with other latent variables (Fornell \& Larcker, 1981). Table 3 demonstrates that the discriminant validity is satisfied, because the value of the root of AVE on the diagonal is higher than all values below for each variable respectively.

Table 5: Discriminant Validity - Heterotrait-monotrait (HTMT)

\begin{tabular}{|c|c|c|c|}
\hline & $\begin{array}{c}\text { Entrepreneurial } \\
\text { intentions }\end{array}$ & $\begin{array}{c}\text { Need for } \\
\text { Achievement }\end{array}$ & $\begin{array}{c}\text { Need for } \\
\text { Independence }\end{array}$ \\
\hline $\begin{array}{c}\text { Entrepreneurial } \\
\text { intentions }\end{array}$ & & & \\
\hline Need for Achievement & 0.346 & & \\
\hline Need for Independence & 0.196 & 0.540 & \\
\hline
\end{tabular}

Source: Authors' calculation

HTMT ratio values below 0.9 indicate that the defined components are sufficiently different from each other; it means that they describe different phenomena (Hair et al., 2019). The results presented in table 5 show that all values are below 0.9 , so it can be concluded that discriminant validity criterion is met.

The Common method bias (CMB) is detected through a full collinearity assessment approach (Kock, 2015). The threshold for the variance inflator factor (VIF) values is 3 (Becker et al., 2015). Hair et al. (2019) agree with the previous mentioned statement, namely that VIF values should be 3 or lower. 
Table 6: Collinearity Statistics

\begin{tabular}{|c|c|}
\hline & VIF \\
\hline Need for Achievement (A2) & 1.169 \\
\hline Need for Achievement (A3) & 1.225 \\
\hline Need for Achievement (A5) & 1.130 \\
\hline Need for Independence (I1) & 1.406 \\
\hline Need for Independence (I2) & 1.855 \\
\hline Need for Independence (I3) & 1.685 \\
\hline Entrepreneurial intentions (Z1) & 2.799 \\
\hline Entrepreneurial intentions (Z2) & 2.939 \\
\hline Entrepreneurial intentions (Z3) & 1.817 \\
\hline
\end{tabular}

Source: Authors' calculation

The multicollinearity analysis indicated that all VIF values presented in Table 3 are below the threshold of 3 $(\mathrm{VIF}<3)$.

The final step of the analysis was to explore relations between psychological characteristics (Need for Achievement and Need for Independence) and entrepreneurial intentions. The data from Table 4 and Figure 2 show the coefficients for PLS-SEM relations and their significance level. The R2, as a coefficient of determination of the model, is very low. Only $7.3 \%$ of the observed variation of the dependent variable (students' entrepreneurial intentions) was explained by independent variables in the model.

Table 7: Mean, Standard Deviation, T-statistics, P-values

\begin{tabular}{|c|l|c|c|c|c|c|c|}
\hline & & \multicolumn{1}{|c|}{$\begin{array}{c}\text { Original } \\
\text { Sample }\end{array}$} & $\begin{array}{c}\text { Sample } \\
\text { mean (M) }\end{array}$ & $\begin{array}{c}\text { Standard } \\
\text { Deviation }\end{array}$ & $\begin{array}{c}\text { T } \\
\text { statistics }\end{array}$ & $\begin{array}{c}\text { p } \\
\text { values }\end{array}$ & Results \\
\hline H1 & $\begin{array}{l}\text { Need for Achievement } \rightarrow \\
\text { Entrepreneurial Intentions }\end{array}$ & 0.220 & 0.223 & 0.045 & 4.932 & 0.000 & Accepted \\
\hline H2 & $\begin{array}{l}\text { Need for Independence } \\
\text { Entrepreneurial Intentions }\end{array}$ & 0.101 & 0.107 & 0.041 & 2.441 & 0.015 & Accepted \\
\hline
\end{tabular}

Source: Authors' calculation

The results displayed in Table 4 demonstrate that all coefficients, which represent the relationship between the independent reflective constructs (Need for Achievement) and the dependent reflective construct (Entrepreneurial Intentions) are in fact positive and statistically significant $(T=4.932 ; p=0.000)$. The results show that the relationship between the independent reflective construct (Need for Independence) and the dependent reflective construct (Entrepreneurial Intentions) is positive and statistically significant $(T=2.441$; $\mathrm{p}=0.015)$.

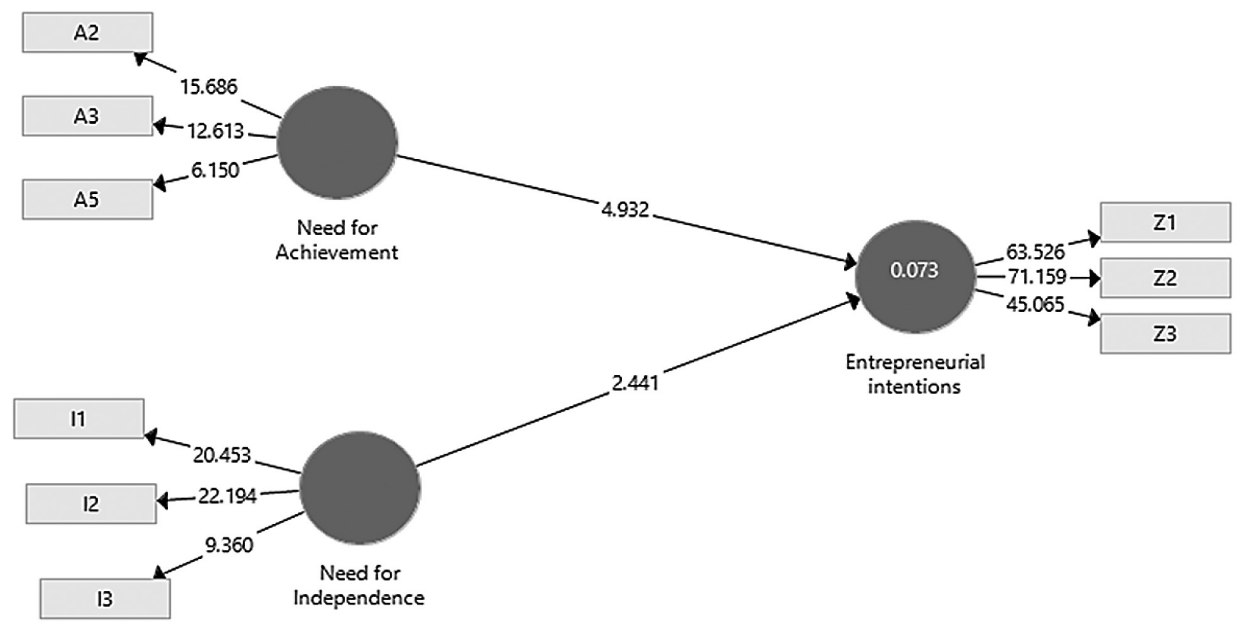

Figure 2: The path model with bootstrapping results

Source: Authors' own research

Based on the results, it can be concluded that both hypotheses $(\mathrm{H} 1$ and $\mathrm{H} 2)$ are confirmed and accepted. The results obtained are in line with previously conducted research which focused on psychological characteristics of students and the connection with their entrepreneurial intentions (Littunen, 2000; Gurol \& Atsan 2006; Popescu et al., 2016, Bjekic \& Strugar, 2019). 
Students, who frequently contemplate various ways of how they could earn much money, who believe that they would enjoy having authority over other people and students, who care about performing better than others on a task, are those particular students who have a need for achievement, and harbour higher entrepreneurial intentions in comparison with students who do not possess these psychological characteristics.

Students who have a need for independence are students for whom it is vital to have the freedom of choice when they do their work; they prefer, as much as possible, to determine the content of their work on their own and they would rather set the sequence of their work tasks independently. These students have higher entrepreneurial intentions than others, who do not have these psychological characteristics.

\section{Conslusion}

Entrepreneurial activity is one of the best means of revitalizing developing economies and meeting the challenges of unemployment. Entrepreneurs play a crucial role and are considered drivers of economic development. Universities should take more initiative in raising awareness as regards the significance of entrepreneurship among young people and in encouraging the development of entrepreneurial spirit. This is the underlying reason for conducting this research. The authors aimed to reveal the entrepreneurial intentions of the students and the factors influencing it. The focus of the research was on the psychological characteristics of students and the linking of those characteristics with the students' entrepreneurial intentions, involving more than 500 students at the Faculty of Economics in Subotica.

The results of the research show that psychological characteristics significantly contribute to entrepreneurial intentions of students, i.e., those students, who have a greater need for achievement and independence are more entrepreneurially oriented than those who do not have those needs. According to these empirically supported results, universities must pay attention to students of all levels of entrepreneurial talent, but specifically make greater efforts to encourage the students with a minor need for achievement and independence to develop these skills. Universities must also stimulate the students with a higher need for achievement in providing venues so they can express their entrepreneurial personalities, e.g., through participating in different students' competitions, as well as through rewarding such students for their success. Furthermore, the universities must motivate and advance those students who have a greater need for independence by having them write the projects of their interest and by triggering them to autonomously organize all resources according to project activities. Also, universities with strong ties to the industry can offer these students a period of business practice, especially in those organizations that are managed in an entrepreneurial way, because in such companies there is a strong tendency for identifying and exploiting opportunities as well as accelerated growth (Eric-Nielesn et al., 2019). The previously mentioned practical implications can be of a huge importance for developing entrepreneurial-minded personalities of students.

The authors believe that the psychological characteristics, crucial for students intending to be entrepreneurs, are insufficient in themselves, thus the introduction of formal entrepreneurial education at the university is likely to contribute to the growth of students' entrepreneurial orientation. Networking the faculties/universities with entrepreneurial educational programmes and entrepreneurship support programmes can present an incentive as a motivating atmosphere for the development of entrepreneurial spirit and a suitable environment for the students who have entrepreneurial intentions.

However, one must keep in mind that, apart from psychological characteristics of the individual and the role of the university, the entrepreneurial intentions of students are influenced by many other factors. For example, complicated administrative processes, the inability to access financial resources, high costs or, simply put, inadequate support at the state level for the development of an entrepreneur can prevent students from deciding to enter the world of entrepreneurs. It is thus the authors' recommendation that at sthe tate level and at the level of the local community things should be made easier for the entrepreneurs in the initial period of development in such a way that upon the completion of their studies, graduates could be offered support when starting an entrepreneurial venture, because only then do the faculty's efforts of support have a specific purpose.

The authors acknowledge that this study has several limitations. One such limit may be that the research was conducted only with students from the Faculty of Economics in Subotica. A further restriction lies in the fact that the research was conducted only at one point in time, therefore making it difficult to determine the trends of this phenomenon. Also, a low coefficient of determination in the model (R2) shows that there are some other factors which determine entrepreneurial intentions, so, apart from the psychological characteristics, it will be important to investigate those, too. This would be the subject of future studies. Following the implementation of the questionnaires, it was not verified whether the entrepreneurial intentions of the students upon graduation were actually realized. In this regard, the authors suggest that future works apply an expanded sample, including students from other faculties of the University of Novi Sad as well as from other universities in Serbia. The inclusion of other faculties will open up the possibility of creating a network to support entrepreneurship and the development of an entrepreneurial spirit in the whole of Serbia, which could prompt young people to seriously consider entrepreneurship, and later to enter the world of entrepreneurs, which would benefit not only them, but could have a positive impact on the Republic of Serbia at all levels. 


\section{REFERENCES}

[1] Ab Hamid, M. R., Sami, W., \& Sidek, M. M. (2017). Discriminant validity assessment: Use of Fornell \& Larcker criterion versus HTMT criterion. Journal of Physics: Conference Series, 890 (1), 012163. DOI: 10.1088/1742-6596/890/1/012163

[2] Ajzen, I., Csasch, C., \& Flood, M. G. (2009). From intentions to behavior: Implementation intention, commitment, and conscientiousness. Journal of Applied Social Psychology, 39(6), 1356-1372. DOI: 10.1111/j.1559-1816.2009.00485.x

[3] Ahmed, I., Nawaz, M. M., Ahmad, Z., Shaukat, M. Z., Usman, A., Rehman, W. U., \& Ahmed, N. (2010). Determinants of students' entrepreneurial career intentions: Evidence from business graduates. European Journal of Social Sciences, 15(2), 14-22.

[4] Ajzen, I. (1991). The theory of planned behavior. Organizational behavior and human decision processes, 50(2), 179-211.

[5] Amidzic R. (2019). A set of factors related to the opportunity motivation: Analysis of Early-stage entrepreneurs from SEE. Strategic Management, 24(2), 45-57. DOI: 10.5937/StraMan1902044A

[6] Bae, T. J., Qian, S., Miao, C., \&Fiet, J. O. (2014). The relationship between entrepreneurship education and entrepreneurial intentions: A meta-analytic review. Entrepreneurship theory and practice, 38(2), 217-254. DOI: 10.1111\%2Fetap.12095

[7] Becker, J.-M., Ringle, C.M., Sarstedt, M. and Völckner, F. (2015),How collinearity affects mixtureregression results. Marketing Letters, 26 (4), 643-659. DOI: 10.1007/s11002-014-9299-9

[8] Begley, T. M., \& Boyd, D. P. (1987). Psychological characteristics associated with performence in entrepreneurial firms and smaller businesses. Journal of business venturing, 2(1), 79-93.

[9] Bird, B.J. (1988). Implementing entrepreneurial ideas: The case for intention. Academy of Management Review, 13, 442-453. DOI: 10.5465/amr.1988.4306970

[10] Bjekic, R., \& Jelaca, Strugar, M. (2019). Students' Entrepreneurial Intention in Respect to their Psychological Traits, Gender and Study Program of the Faculty. Teme, 43(2), 375-394. DOI: 10.22190/TEME180213024B

[11] Bux, S. R., \& Honglin, Y. (2015). Analyzing the impact of the psychological characteristics on entrepreneurial intentions among university students. Advances in Economics and Business, 3(6), 215224. DOI: 10.13189/aeb.2015.030603

[12] Cassidy, T., \& Lynn, R. (1989). A multifactorial approach to achievement motivation: The development of a comprehensive measure. Journal of Occupational Psychology.62(4), 301-312

[13] Chin, W. W. (1998). The partial least squares approach to structural equation modeling. Modern methods for business research, 295(2), 295-336.

[14] Dakduk, S., González, Á., \& Portalanza, A. (2019). Learn About Structural Equation Modeling in SmartPLS With Data From the Customer Behavior in Electronic Commerce Study in Ecuador (2017). SAGE Publications, Limited. DOI: 10.4135/9781526498205

[15] Díez-Echavarría, L., Valencia-Arias, A., Bermúdez-Hernández, J., Maussa Pérez, F., UrregoMarín, M. y Torres Velásquez, J. (2019). Extension of the systemic entrepreneurship intention model in university students.Serbian Journal of Management.14(2). 277-297 DOI: 10.5937/sjm14-17336

[16] Dinis, A., Paço, A.F., Ferreira, J., Raposo, M. \& Rodrigues, R.G. (2013).Psychological characteristics and entrepreneurial intentions among secondary students. Education + Training, 55(8/9), 763-780 DOI: 10.1108/ET-06-2013-0085

[17] EricNielsen, J., Stojanovic-Aleksic, V., \& Zlatanovic, D. (2019). The challenges of managing the entreppreneurial organization. Ekonomika, 65(2), 87-98 DOI: 10.5937/ekonomika1902087E

[18] Ferreira, J. J., Raposo, M. L., Rodrigues, R. G., Dinis, A., \&Paço, A. D. (2012). A model of entrepreneurial intention: An application of the psychological and behavioral approaches. Journal of Small Business and Enterprise Development, 19(3), 424-440. DOI: 10.1108/14626001211250144

[19] Fornell, C., \& Larcker, D. F. (1981). Evaluating structural equation models with unobservable variables and measurement error. Journal of marketing research, 18(1), 39-50. DOI: $10.1177 \% 2 F 002224378101800104$

[20] Franke, N., \&Lüthje, C. (2004). Entrepreneurial intentions of business students-A benchmarking study. International Journal of Innovation and Technology Management, 1(03), 269-288 DOI: 10.1142/S0219877004000209

[21] Grubor, A., Milicevic, N., \& okic, N. (2018). Product availability in the context of retail service quality. Anali Ekonomskog fakulteta u Subotici, (39), 75-88. DOI: 10.5937/AnEkSub1839075G

[22] Gu, J., Hu, L., Wu, J., \& Lado, A. A. (2018). Risk propensity, self-regulation, and entrepreneurial intention: Empirical evidence from China. Current Psychology, 37(3), 648-660.

[23] Gurol, Y. \& Atsan, N. (2006). Entrepreneurial characteristics amongst university students: some insights for entrepreneurship education and training in Turkey. Education+Training, 48(1), 25-38 DOI: 10.1108/00400910610645716 
[24] Hair, J. F., Risher, J. J., Sarstedt, M., \& Ringle, C. M. (2019). When to use and how to report the results of PLS-SEM. European Business Review, 31(1), 2-24. DOI: 10.1108/EBR-11-2018-0203

[25] Hair, J. F., Sarstedt, M., Ringle, C. M., \& Mena, J. A. (2012). An assessment of the use of partial least squares structural equation modeling in marketing research. Journal of the academy of marketing science, 40(3), 414-433. DOI: 10.1007/s11747-011-0261-6

[26] Hair, J. F. J., Sarstedt, M., Hopkins, L., \& Kuppelwieser, V. G. (2014). Partial least squares structural equation modeling (PLS-SEM). European Business Review, 26(2), 106-121.

[27] Hansemark, O. C. (2003). Need for achievement, locus of control and the prediction of business startups: A longitudinal study. Journal of economic Psychology, 24(3), 301-319. DOI: 10.1016/S0167-4870(02)00188-5

[28] Kautonen, T., Van Gelderen, M., \& Fink, M. (2015). Robustness of the theory of planned behavior in predicting entrepreneurial intentions and actions. Entrepreneurship theory and practice, 39(3), 655-674. DOI: $10.1111 \% 2 F e t a p .12056$

[29] Kibler, E., Kautonen, T., \& Fink, M. (2014). Regional social legitimacy of entrepreneurship: Implications for entrepreneurial intention and start-up behaviour. Regional Studies, 48(6), 995-1015. DOI: $10.1080 / 00343404.2013 .851373$

[30] Kock, N. (2015). Common method bias in PLS-SEM: A full collinearity assessment approach. International Journal of e-Collaboration, 11(4), 1-10. DOI: 10.4018/ijec.2015100101

[31] Kolvereid, L. (1996). Organizational employment versus self-employment: Reasons for career choice intentions. Entrepreneurship Theory and Practice, 20(3), 23-31. DOI: $10.1177 \% 2 F 104225879602000302$

[32] Littunen, H. (2000). Entrepreneurship and the characteristics of the entrepreneurial personality. International Journal of Entrepreneurial Behavior \& Research, 6(6), 295-310. DOI: $10.1108 / 13552550010362741$

[33] Maresch, D., Harms, R., Kailer, N., \& Wimmer-Wurm, B. (2016).The impact of entrepreneurship education on the entrepreneurial intention of students in science and engineering versus business studies university programs. Technological forecasting and social change, 104, 172-179. DOI: 10.1016/j.techfore.2015.11.006

[34] Matlay, H., Dinis, A., do Paço, A., Ferreira, J., Raposo, M., \& Rodrigues, R. G. (2013). Psychological characteristics and entrepreneurial intentions among secondary students. Education+ Training. DOI: 10.1108/ET-06-2013-0085

[35] McClelland, D. (1961), The Achieving Society, D. Van Norstrand Co Inc, Princeton, NJ.

[36] Mitrovic, J., \& Mitrovic, V. (2019).The development of social entrepreneurship and the perspective of its further affirmation in the overall development of Serbia. Anali Ekonomskog fakulteta u Subotici, (42), 8197. DOI: 10.5937/AnEkSub1942081M

[37] Nasip, S., Amirul, S. R., Sondoh Jr, S. L., \& Tanakinjal, G. H. (2017). Psychological characteristics and entrepreneurial intention. Education+ Training. 59, 7/8, 825-840. DOI: 10.1108/ET-10-2015-0092

[38] Peterson, R. A., \& Kim, Y. (2013). On the Relationship between Coefficient Alpha and Composite Reliabillity. Journal of Applied Psychology, 98(1), 194-198. DOI: 10.1037/a0030767

[39] Petrovic, M., \& Lekovic, B. (2019). Characteristics of ambitious entrepreneurs in Southeast Europe region: High-growth expectation concept. Anali Ekonomskog fakulteta u Subotici, (41), 55-66. DOI: 10.5937/AnEkSub1941055P

[40] Popescu, C. C., Bostan, I., Robu, I. B., \& Maxim, A. (2016). An analysis of the determinants of entrepreneurial intentions among students: A romanian case study. Sustainability, 8(8), 771. DOI: $10.3390 /$ su8080771

[41] Remeikiene, R., Dumciuviene, D., \& Startiene, G. (2013). Explaining entrepreneurial intention of university students: The role of entrepreneurial education. In Active Citizenship by Knowledge Management \& Innovation: Proceedings of the Management, Knowledge and Learning International Conference 2013, 299-307.

[42] Rodrigues, R. G., Dinis, A., do Paço, A., Ferreira, J., \& Raposo, M. (2012). The effect of an entrepreneurial training programme on entrepreneurial traits and intention of secondary students. Entrepreneurship-Born, made and educated, 77-92.

[43] Pepen, H., \& Pruett, M. (2014). The impact of education, economy and culture on entrepreneurial motives, barriers and intentions: A comparative study of the United States and Turkey. The Journal of Entrepreneurship, 23(2), 231-261. DOI: 10.1177\%2F0971355714535309

[44] Slavtchev, V., Stavroula, L., \& Holger, P. (2012). Effects of entrepreneurship education at universities. Jena Economic Research Papers, 25, 1-33.

[45] Souitaris, V., Zerbinati, S., \& Al-Laham, A. (2007). Do entrepreneurship programmes raise entrepreneurial intention of science and engineering students? The effect of learning, inspiration and resources.Journal of Business venturing, 22(4), 566-591. DOI: 10.1016/j.jbusvent.2006.05.002

[46] Stamboulis, Y., \& Barlas, A. (2014). Entrepreneurship education impact on student attitudes.The International Journal of Management Education, 12(3), 365-373. DOI: 10.1016/j.ijme.2014.07.001 
[47] Statistical Office of the Republic of Serbia (2018). Labour Force Survey,2017, ISSN 0354-3641, available on

[48] Thompson, E. R. (2009). Individual entrepreneurial intent: Construct clarification and development of an internationally reliable metric. Entrepreneurship theory and practice, 33(3), 669-694. DOI: 10.1111\%2Fj.1540-6520.2009.00321.x

[49] Von Graevenitz, G., Harhoff, D., \& Weber, R. (2010).The effects of entrepreneurship education. Journal of Economic Behavior \& Organization, 76(1), 90-112. DOI: 10.1016/j.jebo.2010.02.015

[50] Walter, S. G., Parboteeah, K. P., \& Walter, A. (2013). University departments and self-employment intentions of business students: A cross-level analysis. Entrepreneurship Theory and Practice, 37(2), 175-200. DOI: 10.1111\%2Fj.1540-6520.2011.00460.x

[51] Zhao, H., Seibert, S. E., \& Lumpkin, G. T. (2010). The relationship of personality to entrepreneurial intentions and performance: A meta-analytic review. Journal of management, 36(2), 381-404. DOI: $10.1177 / 0149206309335187$

[52] Zaman, M. (2013). Entrepreneurial characteristics among university students: Implications for entrepreneurship education and training in Pakistan. African Journal of Business Management, 7(39), 4053. DOI: $10.5897 / A J B M 10.290$

[53] Zhang, Y., Duysters, G., \& Cloodt, M. (2014).The role of entrepreneurship education as a predictor of university students' entrepreneurial intention. International Entrepreneurship and Management Journal, 10(3), 623-641. DOI: 10.1007/s11365-012-0246-z

Received: 2020-04-28

Revision requested: 2020-07-05

Revised: 2020-09-17 (2 revisions)

Accepted: 2020-10-20

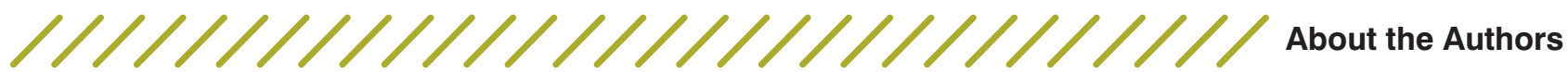

\section{Radmila Bjekić \\ University of Novi Sad, Faculty of Economics in Subotica, Serbia radmila.bjekic@ef.uns.ac.rs}

Radmila Bjekić is a Teaching Assistant at the Faculty of Economics in Subotica, University of Novi Sad, Republic of Serbia. She is an assistant for the scientific area of Management and student of doctoral studies at the Department of Business Economy and Management - module Entrepreneurial Management at the Faculty of Economics in

Subotica, University of Novi Sad. She conducts practical training at the courses of

Organizational Theory and Organizational Design (undergraduate studies). She is the author and coauthor of scientific and professional papers in the fields of human resource management and organizational design that are presented at national and international scientific meetings or published in national and international journals.

\section{Maja Strugar Jelača \\ University of Novi Sad, Faculty of Economics in Subotica, Serbia maja.strugar.jelaca@ef.uns.ac.rs}

Maja Strugar Jelača is an Assistant professor at the Department of Management, Faculty of Economics in Subotica, University of Novi Sad. She teaches courses such as Strategic Management, Management innovation and Management and development at both under and postgraduate levels. Her research primarily aims at: measuring innovative activities in management practice, as well as analyzing different leadership styles to understand what drives the entrepreneurship orientation and innovative success of large organizations. She is the author and co-author of different scientific and professional papers published in national and international research journals.
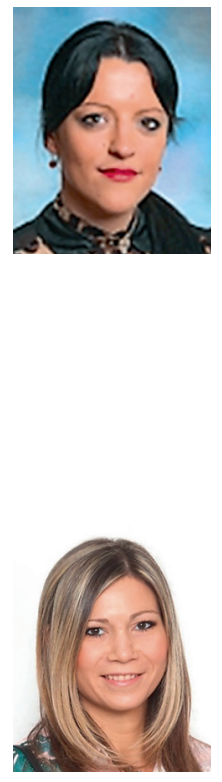


\section{Nemanja Berber}

University of Novi Sad, Faculty of Economics in Subotica, Serbia nemanja.berber@ef.uns.ac.rs

Nemanja Berber is an Assistant Professor at the Faculty of Economics, the University of Novi Sad, the Republic of Serbia. He works in the areas of human resource management, organisational behaviour, urban management, and environmental management. His research interests include human resource management practice in Serbia and Central and Eastern European regions, especially employees' compensation, benefits, and training. He participates in CRANET (The Cranfield Network on International Human Resource Management) and CEEIRT (The Central and

Eastern European International Research Team) projects on HRM and IHRM.

Marko Aleksić University of Novi Sad, Faculty of Economics in Subotica, Serbia marko.aleksic@ef.uns.ac.rs

Marko Aleksić is a Teaching Assistant at the Faculty of Economics in Subotica, University of Novi Sad, Republic of Serbia. He is an assistant for the scientific area of Management and student of doctoral studies at the Department of

Business Economy and Management - module Entrepreneurial Management at the Faculty of Economics in Subotica, University of Novi Sad.

In addition, he is the author and coauthor of numerous scientific and professional papers in the fields of management and ecological economics.
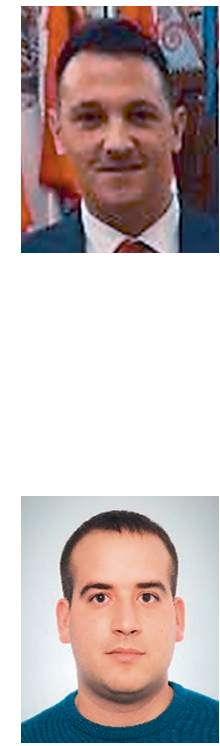